\title{
EFFECTS OF HUMAN FACTORS IN THE EXISTENCE OF BALI STARLING (LeUCopsar rothschildi) THROUGH GEOGRAPHIC INFOMATION SYSTEM APPROACH IN WEST BALI NATIONAL PARK AND NUSA PENIDA BALI
}

\author{
FADLAN PRAMATANA $^{1 *}$, JARWADI BUdI HERNOWO ${ }^{2)}$, AND LILIK BUDI PRASETYO ${ }^{2)}$ \\ 1) Forestry Study Program, Faculty of Agriculture, Nusa Cendana University, Jl. Adi Sucipto Penfui, Kupang, 85001, \\ Indonesia \\ 2) Department of Forest Resources Conservation \& Ecotourism, Faculty of Forestry, Bogor Agricultural University, \\ Darmaga Campus, Bogor, 16680, Indonesia
}

*Email: fadlan.pramatana@staf.undana.ac.id

Accepted September 22, 2020 / Approved June 25, 2021

\begin{abstract}
Bali starling (Leucopsar rothschildi) is one of the animals that getting more attention because is categorized as an endengered species on the IUCN red list, Appendix 1 of CITES, and protected animals by goverment of Indonesia. The conservation for recovery of species was carried out by West Bali National Park (WBNP) through release activity and collaboration with conservation organization for release in different place from their natural habitat. The population of bali starling on both locations is tend to decrease, the study aimed to analized the impact of human factor with the existence of bali starling based on geographic information system. The farthest point of bali starling existence form road distance is 1359 meters on WBNP and 660 meters on Nusa Penida Island, while the closest point on both locations is 0 meter from road distance. The second human factor is village distance with the farthest point of bali starling is 7296 meters on WBNP and 295 meters on Nusa Penida Island, while the closest point of bali starling is 543 meters on WBNP and 0 meter on Nusa Penida Island. The third human factor is community's garden distance with the farthest point of bali starling is 5696 meters on WBNP and 67 meters on Nusa Penida Island, while the closest point of bali starling is 408 meters on WBNP and 0 meter on Nusa Penida Island. The existence point of bali starling that are close to human activites have a negative impact. Bali starling will depend on the resources provided by the community on Nusa Penida Island and part of WBNP and also make it difficult for the bali starling to restore the wild nature for adaptation in natural habitat.
\end{abstract}

Key words: bali starling, geographic information system, human factor, Nusa Penida, West Bali National Park

\section{INTRODUCTION}

Bali starling (Leucopsar rothschildi) is one of the priority species protected under the Indonesian law since 1971 (van Balen et al., 2000). In 1994, this species was listed as Critically Endangered (CR) according to the threatened animal category made by International Union for Conservation of Nature and Natural Resources (IUCN) (Nature et al., 1996). Because there was a mass trade of hundreds of Bali starling in 1960-1970, this species was then regulated by the category of animal trade in the Convention on International Trade in Endangered Species of wild fauna and flora (CITES) with the status of Appendix I or a group of animals that is prohibited to trade freely (van Balen et al., 2000). Various parties have carried out activities to increase this species population, including the Indonesian government which makes order to increase the population of endangered animals according to the IUCN, including Bali starling by $10 \%$ (Regulation of the Director General of Natural Resources and Ecosystem Conservation No.: P.9/IV-SET/2015).

The National Park has a special captivity as Bali starling development center, that is Special Management Unit for Bali Starling Development (UPKPJB) in Tegal Bunder Resort, Management Division of National Park Region II since 1995 (BTNBB 2013). The release of Bali starlings were carried out by TNBB with the Bali Curic Breeders Association (APCB) in soft-release manner by providing food, water, and binding birds around the release sites (Rianto, 2006). Since the release of Bali starlings to live in the wild, the fluctuation was found to be dominated by population decline (BTNBB, 2013). One of the conservation efforts to restore the population of Bali starling in nature was by conducting trial release in the introduction area or outside their natural habitat (BTNBB, 2013). This activity had been carried out in Nusa Penida area of Bali by the Friends of the National Parks Foundation (FNPF) working in collaboration with Bali Government, Udayana University, and Indigenous Institutions at the Nusa Penida District, Klungkung Regency, Bali Province (Sudaryanto, 2016). In 2013, the population of Bali starlings in Nusa Penida area in Ped village was seen at four points with an individual number of approximately 20-25 Bali starlings (Riany and Aunurohim, 2013). However, in 2010, this success was followed by a decline in Bali starling population, which was only 19 birds remaining in Nusa Penida (Sudaryanto, 2016).

One of the problems in Bali starling preservation is the pressure from surrounding community because there are several activities carried out by the surrounding community such as cattle grazing, forest product collection, and animal hunting (Alikodra, 1987). 
Furthermore, Alikodra (1987) stated that Bali starling has biological properties that are very sensitive to disturbances that lead to abnormal reproduction process. This relationship between community pressures and wildlife can be assessed through geographic information system (GIS) approach (Clark et al., 2008; Fryxell et al., 2014). The GIS approach can be used to analyze the biotic and abiotic factors of the landscape and the presence of wildlife (Indrawan et al., 2012).

The number of individuals that have been released continues to experience fluctuations, but it is dominated by declines (Alikodra, 1987; Collins et al., 1998; van Balen, 1999; van Balen et al. 2000). Therefore, this research aims to analyze the effects of human factors in the existence of Bali starlings in the wild through geographic information system approach.

\section{RESEARCH METHOD}

This research was conducted on February-April 2017 in TNBB focusing on Cekik, Pos Lampu Merah,
Brumbun Bay, Labuan Lalang, Menjangan Resort and Ped Village area, Nusa Penida Islands. The research location map is presented in Figure 1.

Tools used in this research were camera, bird guide book by (MacKinnon et al., 2010), Bali administration map, Bali land cover data, Global Positioning System (GPS), DNRGPS software, ArcGIS 10.5. Then, object in this research was bali starling. Data were collected through field observation and map interpretation. Data on the coordinates of Bali starlings were obtained through direct observation using the concentration count method, which means observing animals at a point suspected to be a spot with the highest chance of encounters (Bismark, 2011). The concentration count observation location was determined at the Bali starling release site. It was because Bali starlings in that location obtained controlled resources, such as feed, water, and nest boxes for breeding (Rianto, 2006; Riany and Aunurohim, 2013).

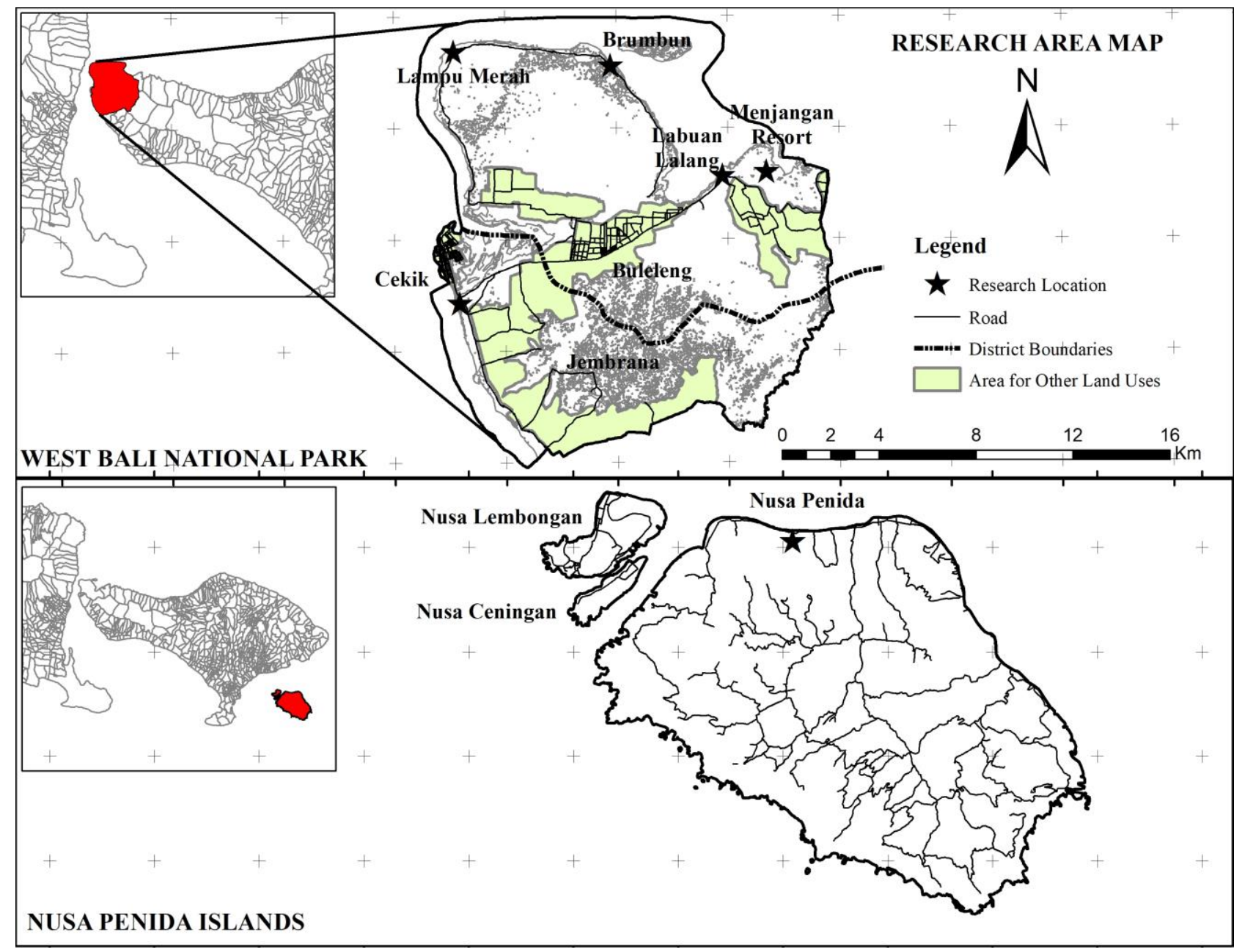

Figure 1 Research Location Map 
Analysis of human factors using geographic information system can be approached through the variables of distance from the road network, distance from villages or settlements, and distance from human activities to the wildlife meeting points (Paga, 2012). Furthermore, Paga (2012) stated that the distance from the road network and settlements represents disturbances from human activities. This variable was also used by Mansyur (2017) who made distance from the road network and settlements as an anthropogenic disturbance. According to Seymour (2006), this disturbance is caused by the accessibility of community to the forest area. The flow of the mapping of the two variables is presented in Figure 2.

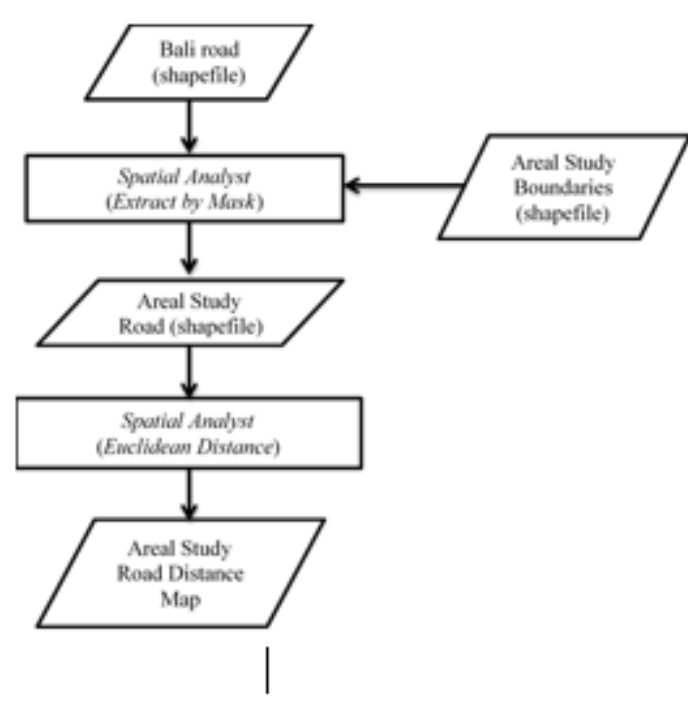

(a)

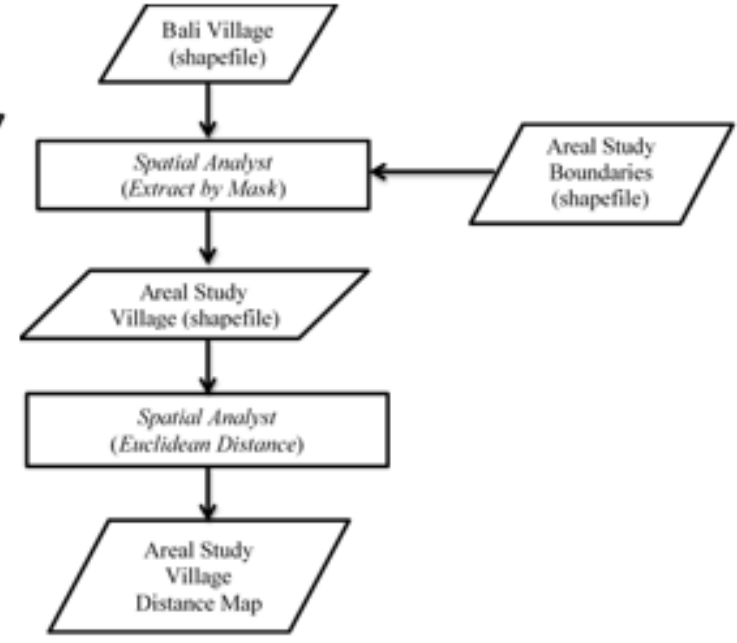

(b)

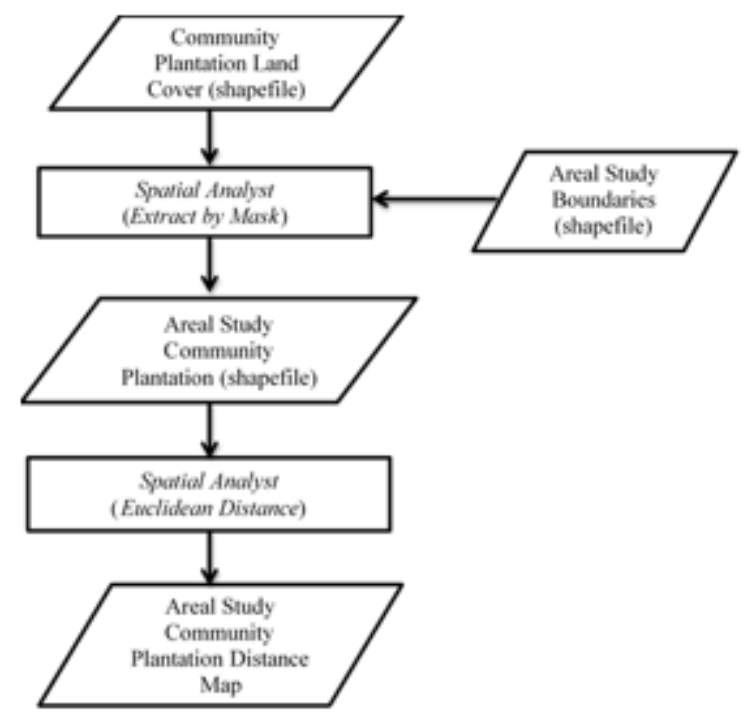

(c)

Figure 2 Variable map creation flow (a) Distance map from the road network; (b) Map of distance from village settlements; (c) Map of distance from community garden 


\section{RESULT AND DISCUSSION}

\section{Distance form Road Network Variable}

TNBB is a National Park area that is accessible by the public. It is passed by the main route from Gilimanuk port to Tabanan and Denpasar (BTNBB, 2016). In addition to its accessibility, there are designated roads to the areas that are often accessed by the public using motor vehicles. Similar conditions were found at the next research location, Nusa Penida Islands having areas planted with coconut (Cocos nucifera L.), cassava (Manihot esculenta Crantz), corn (Zea mays L.), beans (Vigna $s p$.), and are also agricultural lands (Ginantra et al., 2009). It is also one of the destinations for domestic and foreign tourists. According to Agustina (2013), Nusa Penida Islands can develop tours for observing Bali starlings and other flora and fauna. Both of these locations are easy to access, so they can provide various impacts on the existence of Bali starlings. The map of the distance from the road to the point of Bali starling existence is presented in Figure 3.

This map illustrates that Bali starlings' habitat based on the variable of distance from the road in TNBB and Nusa Penida Islands is very close to human activities. The existence of Bali starlings in TNBB cannot be separated from the role of TNBB officers who are near to resort offices providing all Bali starling needs (BTNBB,
2016). This aims to reduce the mortality rate of Bali starlings in the wild caused by their low abilities to do adaptation (BTNBB, 2013). This is one of the factors that causes the point of existence of Bali starling to be close to human activities. The farthest point of the Bali starling from the road network was 1,359 meters or nearly $1.4 \mathrm{~km}$ and the closest point of existence of Bali starling is right on the access road in TNBB or 0 meter from the road network.

The analysis carried out in Nusa Penida Islands related to the variable of distance from the road resulted in a data that was directly proportional to the analysis at the TNBB research location. Bali starlings in Nusa Penida Islands were dominated by starling bird chicks that had no ring and were able to live independently. Bali starling has adapted to Nusa Penida environment according to the initial purpose of the release in 2006 (Sudaryanto, 2016). All of the needs of Bali starling are already available in the plantations of the surrounding community in Nusa Penida Islands (Ginantra et al., 2009; Riany and Aunurohim, 2013). Therefore, Bali starlings in Nusa Penida Islands were found in places close to the community. The farthest point of the Bali starling from the road network was 660 meters or almost $1 \mathrm{~km}$ and the closest point of existence of the Bali starling was right on the access road in TNBB or 0 meter from the road network. The value distribution of distance from the road to Bali starlings' existence point is presented in Figure 4.

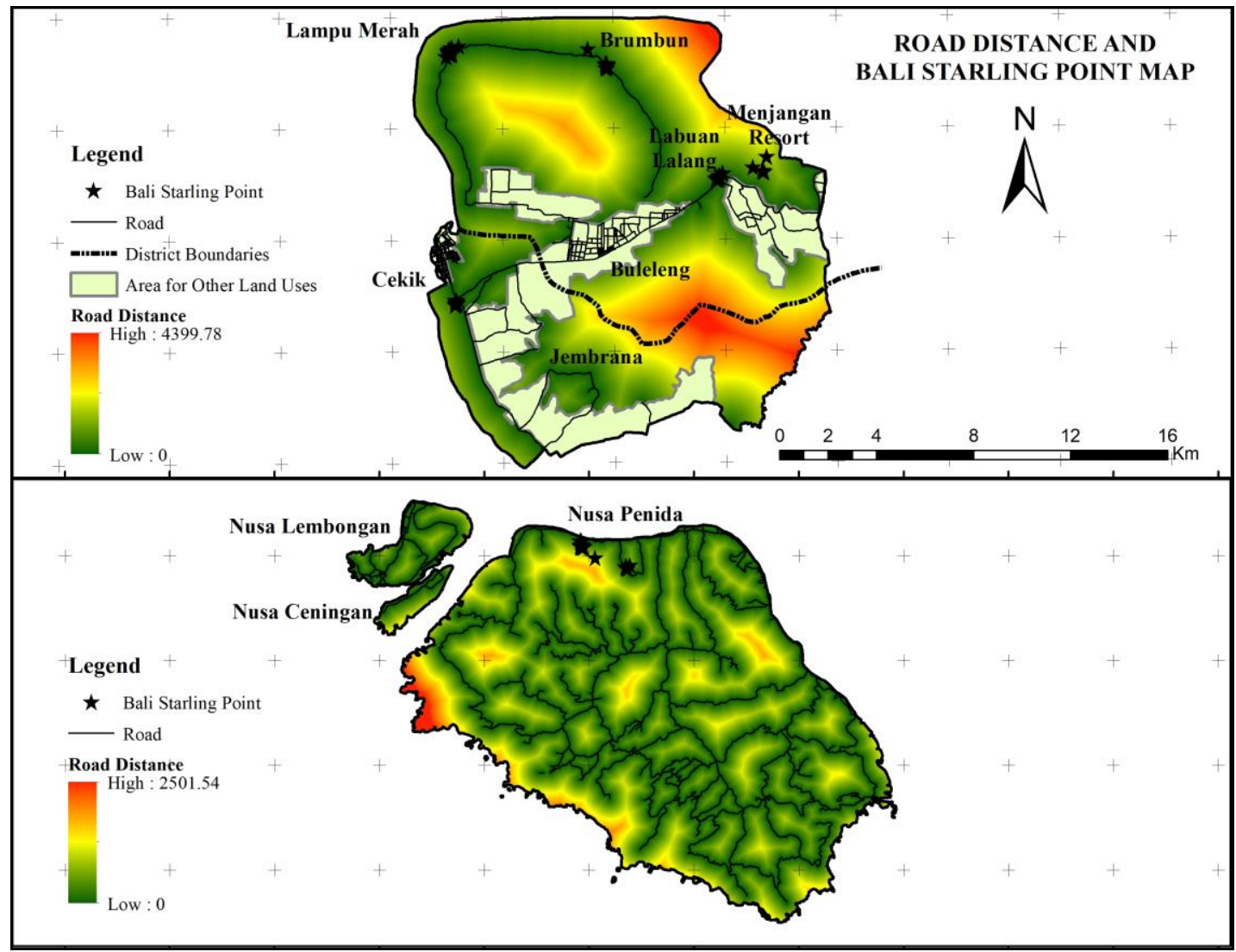

Figure 3. Map of the distance from the road network to the point of of Bali starling 


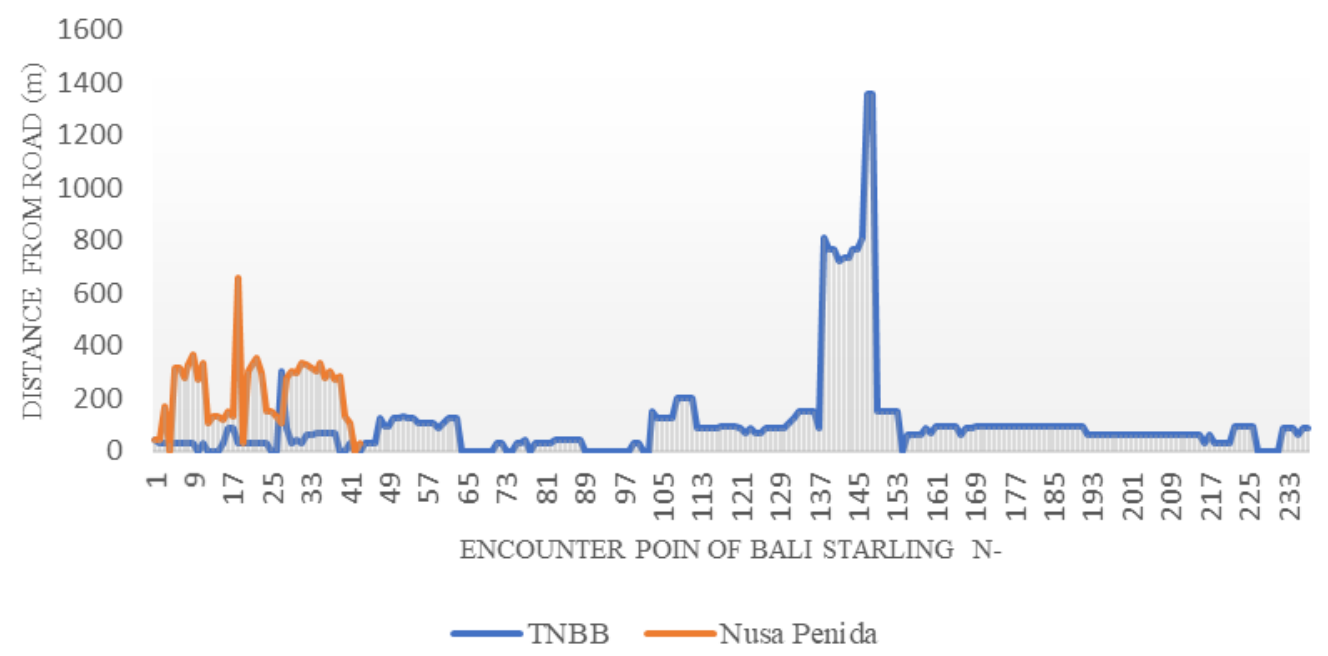

Figure 4. Graph of encounter points of Bali Starling and distance from road network

According to Noerdjito et al., (2011), changes in Bali starlings' habitat began with the change of production forests into plantations, community forests, and settlements. This statement was also supported by van Balen et al., (2000) who stated that the decline in Bali starling population was because their habitat in TNBB had been converted into coconut plantations (Cocos nucifera L.), silk cotton tree (Ceiba pentandra L.), community settlements around the area, and the development of tourism in TNBB area. However, the current condition seems to be the opposite, as the presence of Bali starlings is now commonly found in open areas close to human activities. However, the existence of the Bali starling which is very close to human activities has a negative impact, for example, the birds will be very easy to be found by people who want to hunt them for personal or certain group benefits. Van Balen et al. (2000) stated that there are great losses due to illegal bird hunting in the wild over the past three decades. According to Jepson (2016), it is not easy to perform a successful conservation to save species, especially if people still engage in wildlife trade. Community participation in preserving TNBB environment is one of the keys to preserve Bali starlings (Alikodra, 1987).

\section{Distance from Village Settlement Variable}

TNBB area is adjacent to several villages, including Pejarakan, Melaya, Blimbing Sari, Gilimanuk, and Sumberklampok villages (BTNBB, 2016). Because the close distance from TNBB to the buffer villages, there are many community activities that affect natural resources in the TNBB area, such as honey extraction, animal feed, IPPA (Natural Tourism Permit), and other natural tourism (BTNBB, 2016). The condition of the research location in Nusa Penida Islands is different from TNBB because the location is centered on community settlements.
Nusa Penida Islands consist of 46 cultural villages, 18 service villages, and 79 banjars (Sudaryanto, 2016). Land use in Nusa Penida Islands is dominated by settlement and agriculture with several commodities such as cashew (Anacardium occidentale L.), nuts, mango (Mangifera indica L.), and secondary crops (Tawan et al. 2013). The map of distance from the villages to the point of Bali starling existence is presented in Figure 5.

The farthest point Bali starling existence from the village settlement was7 296 meters or almost $8 \mathrm{~km}$ and the closest point was at 543 meters from the village settlement. In1970s, there was a large-scale trade in this species even though there was national and international government bans. The hunters were from villages within the TNBB area and the Java Island area. Hunting activities were carried out at night by using bait and taking the birds directly from their nest holes. Hunters were also indicated to use nets equipped with telescopes and walkie-talkies to facilitate their hunting (van Balen, 1999). Land clearing and development in the TNBB area initially became one of the factors of the decline in the Bali starling population in the wild because it was considered to decrease their natural habitat (van Balen et al., 2000). The buffer villages around TNBB also pose a threat to Bali starling population, one of which is the threat of hunting by the surrounding community (Alikodra, 1987). According to Collar et al. (2012), in 1999 there was a direct hunt for 39 pairs of Bali starlings in the Management Unit for Bali Starling Development in TNBB.

The existence of Bali starling in Nusa Penida Islands was close to the village area and the activities of the surrounding community. The farthest point of Bali starling from the village settlement was 295 meters and the nearest point was 0 meter or right in the village settlement. It shows that Bali starling is located right in the middle of settlement. Bali starlings in Nusa Penida Islands had been tried to be released to the wild to see 
their adaptation abilities. The release location at that time was at the FNPF department which was right in a community settlement (Sudaryanto 2016). This release showed a positive result that Bali starlings can adapt by using community plantations to meet their needs
(Sudaryanto, 2016). The graph of value distribution of the distance from the village to the point og Bali starlings' existence is illustrated in Figure 6.

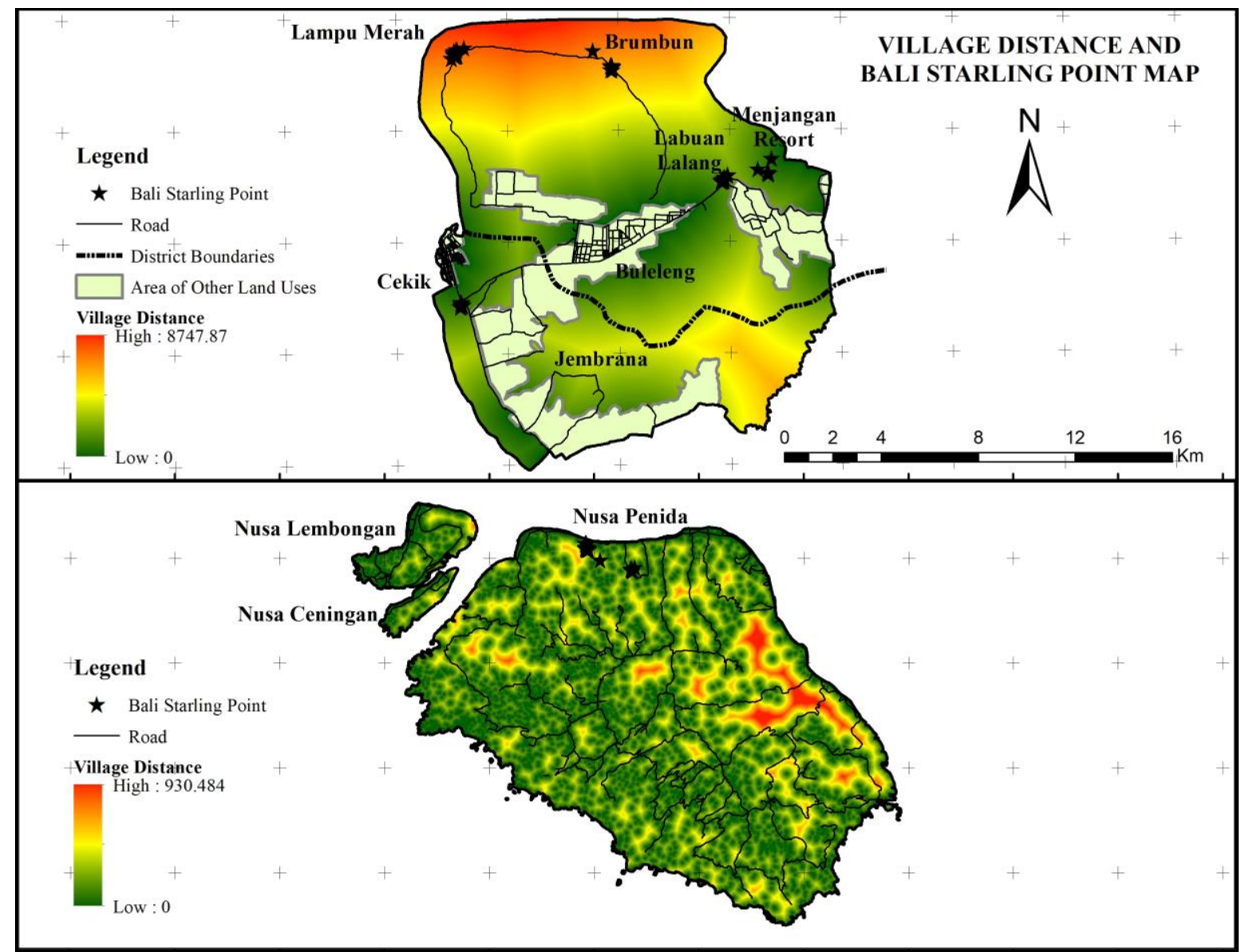

Figure 5. Map of the distance from village settlements to the point of Bali starlings existence

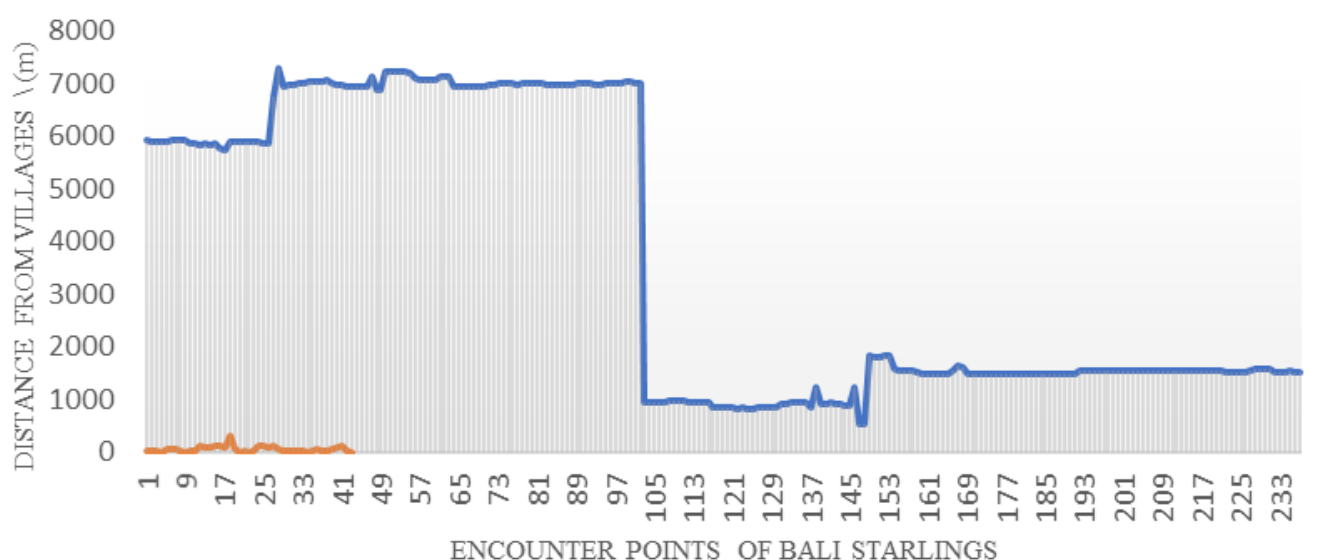

$\longrightarrow$ TNBB $\longrightarrow$ Nusa Penida

Figure 6. Graph of the Encounter Point of Bali Starlings and distance from village settlement 
One of the declines in Bali starling population is cause by the lack of participation of the surrounding community in preserving the TNBB environment, as evidenced by the habits of the people around the TNBB area who often trespass the forest to collect wood, fruit, leaves, grass, graze livestock, and even hunt Bali starlings and other animals. (Alikodra, 1987). Purnamasari (2014) said that conservation actions within the area cannot be carried out alone because it is difficult to achieve sustainable management of Bali starlings, if the people living around the area are not involved in the management activities. Purnamasari (2014) further stated that community empowerment activities are one of the efforts to reduce conflict of interests. Community empowerment is an effort to increase the ability and independence of local communities to obtain optimal and equitable benefits of forest resources through capacity development and access grant in order to improve the welfare of local communities (Regulation of the Minister of Forestry Number: P. 49/Menhut-II/2008). Since 2010, Sumberklampok village has started breeding activities for Bali starlings to improve the economy, increase community participation in Bali starling conservation, and restore the image of Sumberklampok village through Bali starling conservation. A total of 8 out of 14 breeders have succeeded in breeding Bali starlings (Table 1).

Conservation by the community is also carried out in Nusa Penida Islands. The people in Nusa Penida Islands have a good perception of and participation in the awig-awig that protects Bali starling (Sudaryanto et al. 2014). A total of 46 villages implemented awig-awig with protection for birds. The prohibition on hunting birds found in awig-awig is a ban, especially for Bali starlings (Sudaryanto et al., 2014). Furthermore, Sudaryanto et al. (2014) stated that at the alternative level, people are more obedient to awig-awig (47.32\%) compared to formal laws such as Regional Regulations (3.62\%). According to Sudaryanto (2016), every citizen is prohibited from catching, keeping, or trading birds, especially Bali starlings. Sanctions for those who catch birds, poison or shoot birds, and bird sellers are subject to a fine of one sack of rice and money equals to price of the bird in the market. The bird buyers or collectors will be subjected to a fine of two sacks of rice and those who catch birds for pet will be subjected to a fine of half (1/2) sack of rice. If the fine has not been implemented, the relevant person is prohibited from participating in religious ceremonies in the cultural village. If the violation is repeated, the person is ostracized or even expelled from the cultural village. The people are afraid of this moral sanction more because it will embarrasses the extended family (Sudaryanto, 2016). Furthermore, Sudaryanto (2016) said that this awig-awig law also applies to immigrants with a sanction, which is making a report to the authorities.

\section{Distance from Community Plantation Variable}

The change of land use into community plantations and settlements is one of the causes of decline in Bali starling population because it reduces its natural habitat in the TNBB area (van Balen et al., 2000; Noerdjito, 2005). According to van Balen et al. (2000), in 19401974, forests in Java and Bali experienced rapid declines in area and during this period, settlements began to expand to Bali starling area. Land conversion into coconut plantations (Cocos nucifera L.), silk cotton tree (Ceiba pentandra L.), and settlements replaced almost the entire habitat of the Bali starling. The existence of Bali starling until the 1980s was outside TNBB, along the north and south seas of western Bali (van Balen et al. 2000). Furthermore, van Balen et al. (2000) said that development projects for tourism centers and infrastructure pose a threat to TNBB, especially Bali starling habitat. The map of the distance from community plantations to the point of Bali starling existence is presented in Figure 7.

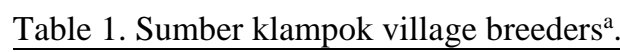

\begin{tabular}{cccc}
\hline Breeder & Number of parents (pair) & Birthrate (individual) & Mortality rate (individual) \\
\hline 1 & 1 & 2 & 2 \\
2 & 2 & 22 & 8 \\
3 & 3 & 10 & 9 \\
4 & 1 & 0 & 0 \\
5 & 1 & 16 & 10 \\
6 & 3 & 24 & 0 \\
7 & 1 & 0 & 5 \\
8 & 1 & 14 & 3 \\
9 & 1 & 4 & 0 \\
10 & 1 & 0 & 0 \\
11 & 0 & 0 & 7 \\
12 & 3 & 15 & 1 \\
14 & 0 & 0 & 0 \\
\hline
\end{tabular}

aSource: Purnamasari (2014) 
Van Balen et al. (2000) stated that decline in forest area changed into settlements and plantations allegedly occurred in other use areas consisting of village areas and HTI (Industrial Plantation Forests). In 1982, according to community reports, Bali starlings bred in coconut plantations (Cocos nucifera L.) (van Balen et al., 2000). This indicated that the Bali starlings were in the process of assimilation before they were expelled by hunters (van Balen et al., 2000).

The farthest point of Bali starling from the community plantations in TNBB was 5696 meters or almost $6 \mathrm{~km}$ and the closest point was 408 meters. The encounter point of the Bali Starling in TNBB is influenced by the soft release method. Bali starlings are concentrated in these release areas, because Bali starlings obtain controlled resources, such as feed, water, and nest boxes for breeding (Rianto, 2006; Riany and Aunurohim, 2013). The migration of the Bali starling in TNBB is not far from the release locations. This result is in accordance with Sudaryanto (2016) that the displacement and home range of the Bali starling is influenced by the source of food. The graph of the distribution of distance from community plantations to the points of Bali starling is presented in Figure 8.

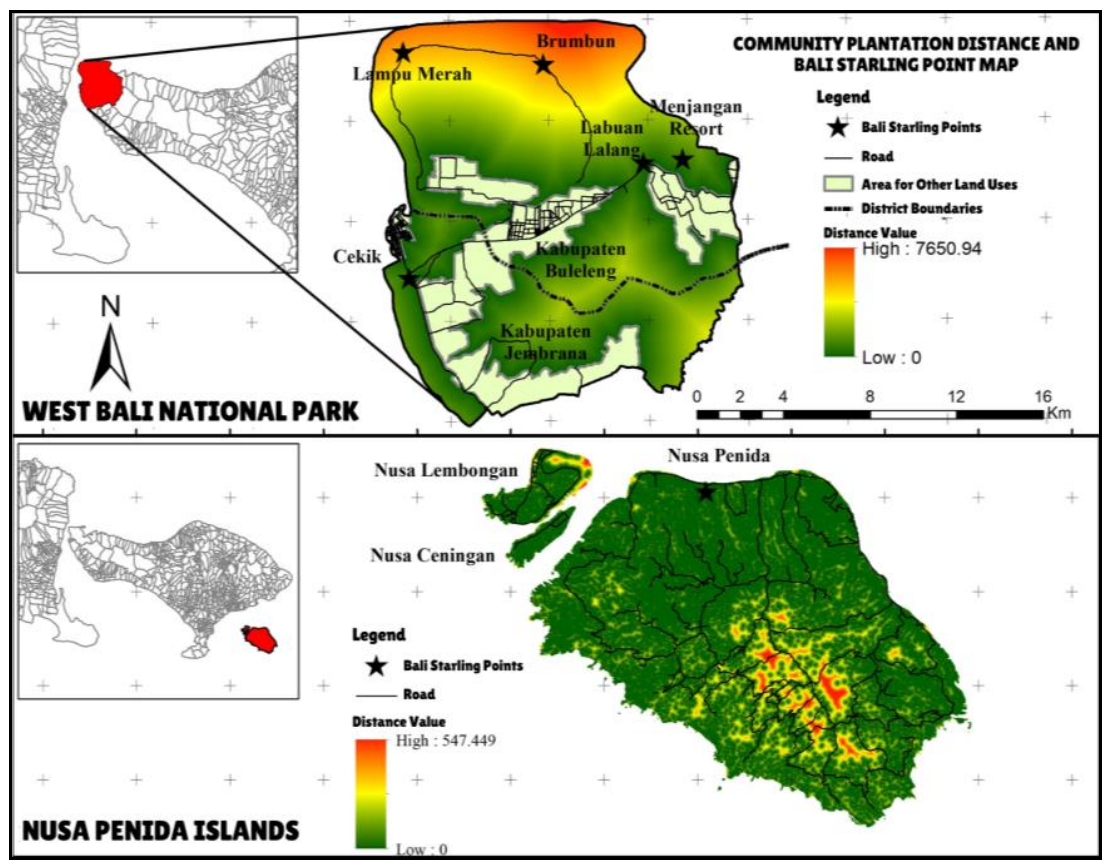

Figure 7. Map of the distance from the community plantations to the point of Bali starlings existance

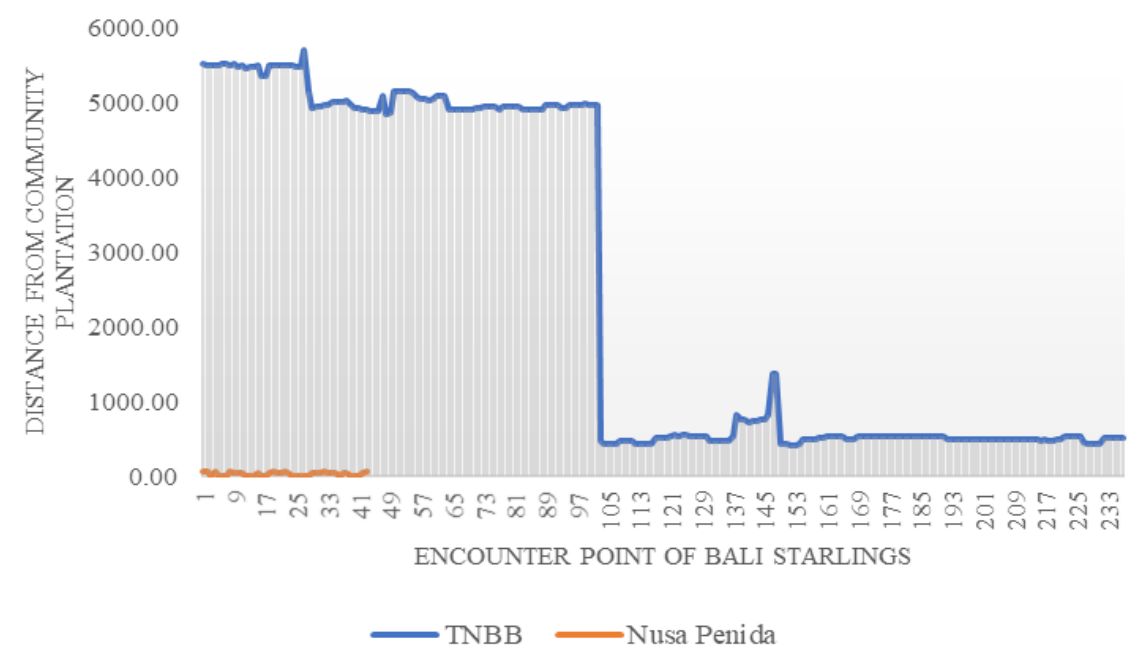

Figure 8. Graph of Bali Starling encounter points and distance from community plantation 
The farthest point of Bali starling from the community plantation in Nusa Penida was 67 meters and the closest point was 0 meters or right on the community plantation. Vegetation conditions in Nusa Penida area are different from the natural habitat of Bali starlings in West Bali National Park (Ginantra et al., 2009; Riany and Aunurohim, 2013; Sudaryanto, 2017), but in this area the released Bali starlings can survive and breed by utilizing natural trees for nesting in addition to artificial nesting boxes (Riany and Aunurohim, 2013; Sudaryanto, 2017). Land use in Nusa Penida Islands is dominated by plantations, settlements and agriculture land (Sudaryanto, 2016). According to Ginantra et al. (2009), Nusa Penida Islands are planted with coconut (Cocos nucifera L.), cassava (Manihot esculenta Crantz), corn (Zea mays L.), beans (Vigna sp.), and agricultural lands.

The development of Bali starling population in Nusa Penida Islands from 2006 to 2015 experienced fluctuations which were dominated by an increase in the number of its individuals (Sudaryanto, 2016). This success was followed by a decline in 2010, in which there were only 19 Bali starling population remained in Nusa Penida (Sudaryanto, 2016). The first release of Bali starling in Nusa Penida Islands was carried out to know its adaptability in habitats different from the natural habitat of TNBB (Sudaryanto, 2016). Bali starlings in Nusa Penida Islands can meet all their needs and breed well in local residents' plantations. This is inseparable from the assistance of the locals to protect Bali starlings, which are considered a sacred animal (Sudaryanto, 2016).

The existence of Bali starling which is close to community activities has a negative impact because the development of the bird will always depend on the resources provided by the community and the TNBB. In addition, it is difficult for Bali starlings to regain their wild nature. Prevention of hunting in TNBB and Nusa Penida needs to be improved, given that the Bali starlings existence are very close to human activities.

\section{CONCLUSION}

Human factor on the existence of Bali starlings in TNBB and Nusa Penida Islands has a negative impact. The habitat of Bali starlings that is relatively close to the road network, village settlements, and community plantations results in the dependence on the provided resources. The existence of Bali starlings, which is close to human activities also makes it difficult for them to restore their wild nature to survive in the wild.

\section{REFERENCES}

Agustina, R. 2013. Strategi pengembangan ekowisata jalak bali (Bali Starling) berbasis masyarakat Di Pulau Nusa Penida Kabupaten Klungkung.
[Tesis]. Bali: Program Pasca Sarjana Universitas Udayana.

Alikodra HS. 1987. Masalah pelestarian jalak bali. Media Konservasi. 1(4): 21-28.

Bismark M. 2011. Prosedur Operasi Standar (SOP) untuk survei Keragaman Jenis Pada Kawasan Konservasi. Bogor: Pusat Penelitian dan Pengembangan Perubahan Iklim dan Kebijakan, Badan Penelitan dan Pengembangan Kehutanan, Kementerian Kehutanan.

BTNBB. 2013. Rencana Induk (Grand Design) Pelestarian Curik Bali di Taman Nasional Bali Barat, 2013-2017. Bali: BTNBB.

BTNBB. 2016. Statistik Balai Taman Nasional Bali Barat. Bali: BTNBB.

Clark RD, Mathieu R, Seddon PJ. 2008. Geographic information systems in wildlife management: A case study using yellow-eyed penguin nest site data. Department of Conservation.

Collar NJ, Gardner L, Jeggo DF, Marcordes B, Owen A, Pagel T, Pes T, Vaidl A, Wilkinson R, Wirth R. 2012. Conservation breeding and the most threatened birds in Asia. BirdingASIA. 18:50-57.

Collins MS, Smith TB, Seibels RE, Putra IMWA. 1998. Approaches to the reintroduction of the Bali mynah. Zoo Biol Publ Affil with Am Zoo Aquarium Assoc. 17(4):267-284.

Fryxell JM, Sinclair ARE, Caughley G. 2014. Wildlife ecology, Conservation, and Management. New Jersey: John Wiley \& Sons.

Ginantra IK, Dalem AAG, Sudirga SK, Wirayudha I. 2009. Jenis-jenis tumbuhan sebagai sumber pakan Jalak Bali (Leucopsar rothschildi) di Desa Ped, Nusa Penida, Klungkung Bali. J Bumi Lestari. 9(1):97-102.

Indrawan M, Primack RB, Supriatna J. 2012. Biologi Konservasi: Edisi Revisi. Bogor: Yayasan Pustaka Obor Indonesia.

Jepson PR. 2016. Saving a species threatened by trade: a network study of Bali starling Leucopsar rothschildi conservation. Oryx. 50(3):480-488.

MacKinnon J, Phillipps K, Van Balen B. 2010. Burungburung di Sumatera, Jawa, Bali dan Kalimantan. BogorL Burung Indonesia.

Mansyur FI. 2017. Model kesesuaian habitat tarsius (Tarsius sp.) di hutan Lambusango Pulau Buton Provinsi Sulawesi Tenggara [tesis]. Bogor (ID): Institut Pertanian Bogor.

Nature IU for C of, Centre ICM, Centre WCM, Nature IU for C of, Commission NRSS, Preservation IC for B, International B. 1996. IUCN red list of threatened animals. International Union for Conservation of Nature and Natural Resources.

Noerdjito M. 2005. pola persarangan curik bali (Leucopsar rothscliildiStresemann, 1912) dan kerabatnya di taman nasional bali barat. Ber Biol. 7(4):215-222. 
Noerdjito M, Roemantyo R, Sumampau T. 2011. Merekonstruksi Habitat Curik Bali Leucopsar rothschildi Stresemann, 1912 di Bali Bagian Barat. J Biol Indones. 7(2):341-359.

Paga B. 2012. Karakteristik habitat burung cikukua timor (Philemon inornatus) di Lanskap Camplong Kabupaten Kupang, Nusa Tenggara Timur [tesis]. Bogor: Institut Pertanian Bogor.

Purnamasari I. 2014. Model keberhasilan penangkaran jalak bali (leucopsar rothschildi stresemann, 1912) berdasarkan peubah sosial masyarakat [tesis]. Bogor: Institut Pertanian Bogor.

Rianto T. 2006. Review Faktor Pembatas Ekologi dalam Upaya Pengembalian Populasi Liar Jalak Bali (Leucopsar rothschildi) Taman Nasional Bali Barat. Cekik Bali.

Riany CF, Aunurohim A. 2013. Populasi Burung Jalak Bali (Leucopsar rothschildi, Stresemann 1912) Hasil Pelepasliaran di Desa Ped dan Hutan Tembeling Pulau Nusa Penida, Bali. J Sains dan Seni ITS. 2(2):E186-E190.

Seymour A. 2006. Summary of biological and sociological research carried out by Operation Wallacea in the forest of Central Buton. Jakarta: Oper Wallacea-Indonesia Program.
Sudaryanto, Djohan CS, Pudyatmoko S, Subagja J. 2014. Pelaksanaan awig-awig faktor keberhasilan biologi konservasi jalak bali (Leucopsar rothschildi Stresemann 1912) di Kepulauan Nusa Penida [Prosiding]. Seminar Nasional Biosains I. Bali: Universitas Udayana.

Sudaryanto. 2016. Konservasi jalak bali (Leucopsar rothschildi) di Kepulauan Nusa Penida [Disertasi]. Jogja: Universitas Gadjah Mada.

Sudaryanto. 2017. Awig-awig faktor keberhasilan konservasi Jalak Bali (Leucopsar rothschildi Stresemann, 1912) di kepulauan Nusa Penida. Konferensi Peneliti dan Pemerhati Burung Indonesia 3 Bali.

Tawan IG, Suryadi M, Treman IW. 2013. Karakteristik Kawasan Karst Di Pulau Nusa Penida Kecamatan Nusa Penida Kabupaten Klungkung (Kajian Geomorfologi). J Pendidik Geogr Undiksha. 1(2).

van Balen S (Bas), Dirgayusa IWA, Adi Putra IMW, Prins HHT. 2000. Status and distribution of the endemic Bali starling Leucopsar rothschildi. Oryx. doi:10.1017/s0030605300031185.

van Balen S. 1999. Birds on fragmented islands: persistence in the forests of Java and Bali. Chem Eng $J$. 